\title{
Reponses of Tomato (Lycopersicon Lycopersicum Mill), Soil Temperature and Soil Moisture Content to Mulch Material and Mulching Rate in Ogbomoso and Mokwa, Nigeria
}

\author{
Tswanya $\mathrm{MN}^{1 *}$, Olaniyi JO ${ }^{2}$ and Alamu $\mathrm{LO}^{3}$ \\ ${ }^{1}$ Biotechnology Advanced Research Centre, Nigeria \\ ${ }^{2}$ Department of Agronomy, Ladoke Akintola University of Technology, Nigeria \\ ${ }^{3}$ Department of Crop Production and Environmental Protection, Ladoke Akintola University of Technology, Nigeria
}

Submission: August 27, 2017; Published: October 27, 2017

*Corresponding author: Tswanya MN, Biotechnology Advanced Research Centre, Sheda Science and Technology Complex, P.M.B. 186, Garki-Abuja, Nigeria, Email: ndamayakimatthew@gmail.com

\begin{abstract}
Field experiments were conducted at the Teaching and Research Farm, Ladoke Akintola University of Technology, Ogbomoso and Niger State College of Agriculture, Mokwa, in 2014 cropping season to examine the effects of mulch materials and mulching rates on fruit yield, soil temperature and soil moisture content of tomato variety. The experiment had fifteen treatments viz: three mulch materials (rice husk, groundnut shell and dry guinea grass) and five mulching rates $\left(0,5,10,15, \& 20\right.$ in t ha- $\left.{ }^{-1}\right)$, replicated three times. The experiment was laid out as split plot arranged in Randomized Complete Block Design. Data were collected on plant height, number of flowers, number of fruits and total fruit yield. Two environmental factors (soil temperature and soil moisture content) were determined. Data was analysed using analysis of variance (ANOVA) SAS package and treatment means compared using least significant difference (LSD) at 5\% probability level. Mulching is beneficial to performance of tomato. Mulch types had no effect on fruit yield of tomato. Plants mulched with $15 \mathrm{t} \mathrm{ha}^{-1}$ produced the highest yield $\left(23.30 \mathrm{t} \mathrm{ha}{ }^{-1}\right)$ while control plots had the least value $\left(8.13 \mathrm{t} \mathrm{ha}^{-1}\right)$. Soil temperature was best at mulching rate of $15 \mathrm{t} \mathrm{ha}^{-1}$ and soil moisture content was at $20 \mathrm{t}$ $\mathrm{ha}^{-1}$. It could be concluded that mulching is beneficial to tomato production; mulch rate of $15 \mathrm{t} \mathrm{ha}^{-1}$ performed better than other rates evaluated and could be recommended for the farmers within the study areas.
\end{abstract}

Keywords: Tomato; Mulching material; Mulching rate; Growth; Yield; Soil temperature; Soil moisture content

\section{Introduction}

Tomato (Lycopersicon lycopersicum) belongs to the solanaceae family. It originated in Peru and Mexico, in the present day Central and South America from where it spread to other parts of the world [1]. Tomato reached Europe from Mexico in the 16th century, and was initially used as ornamental plant. Its cultivation for edible fruits started at the end of the 18th century. Tomato was introduced to West Africa and Nigeria in particular, at the end of the 19th century [2]. It is currently considered to be one of the main vegetable crops in the world, and constitutes an economic force that influences the income of many growers in the world [3]. In Nigeria tomato also finds its way into almost every kitchen. Tomato crop is very important in terms of diet and economy in Nigeria both during the rainy season (rainfed) and dry season using irrigation facilities. It is used as a condiment in stews and soup or eaten raw in salads. Industrially, the crop is made into puree, sauce, paste and powder [4].

Mulching is the process or practice of covering the soil/ ground to make more favorable conditions for plant growth, development and efficient crop production. Mulch technical term means 'covering of soil' [5]. While natural mulches such as leaf, straw, dead leaves and compost have been used for centuries, during the last 60 years the advent of synthetic materials has altered the methods and benefits of mulching. When compared to other mulches plastic mulches are completely impermeable to water; it therefore prevents direct evaporation of moisture from the soil and thus limits the water losses and soil erosion over the surface [6]. In this manner it plays a positive role in water conservation and the suppression of evaporation also has a supplementary effect; it prevents the rise of water containing salt, which is important in countries with high salt content water resources [7].

Mulching is a layer of material on the surface of the soil used to keep soil moist or to serve a wide variety of other purposes. Organic mulches are those derived from the dead plant and animal tissues, which apart from soil protection also serve as nutrient sources when they decay. Tomato plants subjected to 
mulching and fertilization exhibited the highest plant height when compared with the other treatment combinations [8]. Mulching has been identified by many researchers as a method to provide a favorable soil environment by minimizing crusting at the soil surface and keep it stable [9]. Influence of mulching on tomato production has been reported by many researchers [10]. This practice increases the infiltration of rain water and suppresses the growth of weeds. Mulching is effective in reducing evaporation, conserving soil moisture and has been known to modify the hydrothermal regime of soil [11].

Mulching of tomato plants with Tithonia diversifolia leaves and fertilizer application together promoted growth and development i.e. number of nodes, number of leaves and height, as well as fruit production i.e. number of fruits, number of seeds per fruit, fruit size, fruit shape and duration of fruiting activity. In the experiment conducted by [9], three tomato varieties namely, Ratan, BARI tomato-3 and BARI tomato-6 were experimentally evaluated to identify the potential mulch on growth and yield, where the experiment consisted of four mulching treatments: water hyacinth, straw, am-ada leaf and banana leaf with a control (no mulch). The experiment was conducted under rainfed condition. The result showed that mulching significantly had effect on growth, yield components and thus on the yield of tomato. Mulching is effective in reducing evaporation, conserving soil moisture and has been known to modify the hydrothermal regime of soil [11]. The bad effects of water deficit could be overcome by irrigation or adopting in-situ moisture conservation techniques, such as use of mulches [12].

Mulches are effective in reducing soil moisture loss from evaporation. Organic mulches are effective, but when moisture is applied by irrigation or through rainfall, the amount should be adequate to reach the soil. Organic mulches tend to settle with time. Some are less resistant and decompose after a short time. As such, it may be necessary to add fresh material to the original layer to make it effective in retaining moisture [13]. The agronomic characteristics of tomato as influenced by irrigation and mulching were examined. Mulching and no mulching were evaluated. Rice straw was used as mulching material at the rate of 5t/ha. The mulching significantly affected the fruit yield in such a way that mulched plots produced about two times more fruit yield than those without mulch [14]. The effects of L. Leucocephala and G. Sepium mulches (and their mixtures) on the growth and yield of okra was assessed. The mulches were applied at the rate of $0,5 \& 10 \mathrm{tha}^{-1}$. The mulches did not significantly improve the chemical properties of the soil, but improved the growth rate and yield of okra. Generally, the higher the amount of mulch applied, the better the growth and yield of okra [15]. Mulching, using any of the materials like green leaves, dried leaves and coconut fronds significantly increased tomato fruit yield by $65.30 \%$ over the control and they attributed the increase to the slight improvement in the physical properties of soil [16]. Similarly, mulches applied at very low rates e.g. $2.5 \mathrm{t}$ ha-1 or 5 t ha ${ }^{-1}$ can significantly increase growth and yields of highly valuable vegetable and fruits crops in the field [17].

Trash farming suppresses weed germination and retard growth and development of many weeds, reduces soil erosion and conserves soil moisture. In the low and intermediate rainfall areas, tomato is mulched with trash [18]. This helps in conservation of soil moisture and fertility [19]. Soil temperature increased the yield of tomato significantly when mulching material was applied than the control plot. The highest soil temperature occurred under organic mulch which was 2.2 to $3.4{ }^{0} \mathrm{C}$ more than the bare soil. Consequently, the soil flux is substantially greater under mulch. They concluded that this study had demonstrated the benefits of organic mulching on tomato yield. Mulching resulted in 21.7 to $29.8 \%$ increase in fruit yield as compared to bare soil. It also increases the soil temperature which helps in establishing the early planting of tomato plants in cold areas [20].

Various factors affect the quality and yield of tomatoes, among which are inadequate use of available moisture and nutrients, and in-hospitable temperature. Organic mulches are used in many horticultural crops to raise soil temperature, suppress weeds and conserve soil water [21]. Traditionally, organic mulches are dry grass and plant residue mulches which are often used to warm soil early in the season. Soil mulching not only reduces the soil evaporation and weed growth but also improves the aerial environment around the plants which facilitate plant growth and yield. Use of mulches for early crop offers great scope in such a situation because of conserving moisture and improving soil temperature [10]. In an experiment conducted by Agele et al. [22] on mulching using sunflower discovered that the organic mulch materials improved soil moisture status in both trials. However, dry grass and teak leaf increased soil moisture contents significantly over those obtained under polythene sheet mulch and control. They further stated that soil moisture content improved considerably following decreases in soil temperature in plots mulched with dry grass and teak leaves.

Despite many investigations in the area of nutrition, knowledge on how mulching material and mulching rates influences physical and phytochemical contents of tomato fruit is insufficient. This study determined fruit yield of tomato, soil temperature and soil moisture content in Ogbomoso and Mokwa, Nigeria as influenced by mulch materials and mulching rates.

\section{Materials and Methods}

The experiment was conducted at two locations; Teaching and Research Farm, Ladoke Akintola University of Technology, Ogbomoso $\left(8^{0} 101 \mathrm{~N} ; 4^{0} 101 \mathrm{E}\right)$ and Niger State College of Agriculture, Mokwa $\left(9^{0} 181 \mathrm{~N}\right.$ and $\left.5^{\circ} 041 \mathrm{E}\right)$, during 2014 cropping season. The experimental plot was ploughed and harrowed after which lining out was carried out. There were 45 plots with three replications. Each replicate consisted of 15 plots. Each treatment was in a bed plot size of $2.5 \mathrm{~m} \times 2.0 \mathrm{~m}(5.00 \mathrm{~m} 2)$. A plot contained 
25 plants. The total experimental area was $405.00 \mathrm{~m} 2(0.041$ ha $^{-1}$ ). The alley way between replicates was $1.0 \mathrm{~m}$ and within replicates was $1.0 \mathrm{~m}$ with inter and intra-row spacing of $50 \mathrm{~cm} \mathrm{x}$ $50 \mathrm{~cm}$. Three mulch materials that were used included: Rice husk, Groundnut shell and Dry guinea grass while the mulching rates involved: $0,5,10,15 \& 20 \mathrm{tha}^{-1}$. The test crop used was UC82B tomato variety. The treatment was laid out as split plot arranged in Randomized Complete Block Design, replicated three times.

The seeds were sourced from the Department of Crop Production and Soil Science, Ladoke Akintola University of Technology, Ogbomoso and from the Department of Agricultural Technology, Niger State College of Agriculture, Mokwa. The tomato seeds were sown on nursery beds containing pulverized soil and the seedlings were raised for four weeks before transplanting to the field at the two locations. Watering in the nursery was done as at when needed. Healthy and vigorous seedlings were transplanted into the field in order to ensure uniformity. Watering

\section{Results}

\section{Plant height (cm)}

Table 1: Effect of mulch material and mulching rate on plant height of tomato plants in 2014 cropping season.

\begin{tabular}{|c|c|c|c|c|c|c|}
\hline \multicolumn{7}{|c|}{ Plant Height (cm) } \\
\hline \multicolumn{7}{|c|}{ Mulching Rate ( $\mathrm{t} \mathrm{ha}^{-1}$ ) } \\
\hline Mulch Material & $\mathbf{0}$ & 5 & 10 & 15 & 20 & MM Mean \\
\hline \multicolumn{7}{|c|}{ 2WAT } \\
\hline $\mathrm{RH}$ & 18.9 & 20.4 & 25.7 & 23.3 & 23.6 & 22.4 \\
\hline GS & 20.7 & 22.4 & 21.9 & 26.3 & 21 & 22.5 \\
\hline DG & 24.4 & 20.1 & 24 & 26.7 & 20.8 & 23.2 \\
\hline MR Mean & 21.3 & 21 & 23.9 & 25.4 & 21.8 & \\
\hline LSD (0.05) MM & ns & & & & & \\
\hline MR & 2.89 & & & & & \\
\hline MM x MR & ns & & & & & \\
\hline \multicolumn{7}{|c|}{ 4WAT } \\
\hline RH & 30.9 & 28.7 & 39.2 & 39.7 & 39.9 & 35.7 \\
\hline GS & 29.2 & 34.9 & 31.7 & 40.9 & 31 & 33.5 \\
\hline DG & 31.3 & 30.4 & 35.8 & 39 & 34.5 & 34.2 \\
\hline MR Mean & 30.5 & 31.3 & 35.6 & 39.9 & 35.1 & \\
\hline LSD (0.05) MM & ns & & & & & \\
\hline MR & 3.65 & & & & & \\
\hline$M M \times M R$ & ns & & & & & \\
\hline \multicolumn{7}{|c|}{ 6WAT } \\
\hline RH & 28.6 & 32.4 & 34.6 & 41.1 & 36.3 & 34.6 \\
\hline GS & 30.7 & 34.5 & 35.5 & 38.7 & 41.1 & 36.1 \\
\hline DG & 28.6 & 34 & 36.1 & 39.8 & 38 & 35.3 \\
\hline MR Mean & 29.3 & 33.6 & 35.4 & 39.9 & 38.5 & \\
\hline
\end{tabular}




\section{Current Trends in Biomedical Engineering \& Biosciences}

\begin{tabular}{|c|c|l|l|l|l|l|}
\hline LSD (0.05) MM & $\mathrm{ns}$ & & & & \\
\hline MR & 2.8 & & & & & \\
\hline MM x MR & $\mathrm{ns}$ & & & & & \\
\hline
\end{tabular}

RH: Rice Husk; GS: Groundnut Shell; DG: Dry Guinea Grass; MM: Mulch Material; MR: Mulching Rate; NS: Not Significant; (P $\leq 0.05)$; LSD: Least Significant Difference

Application of different mulch material had no significant $(\mathrm{P} \geq 0.05)$ effect on the plant heights of tomato plants at all the sampling periods (Table 1). The plant heights of tomato was significantly $(\mathrm{P} \leq 0.05)$ influenced by mulching rate at 2 WAT. The plants mulched with $15 \mathrm{t} \mathrm{ha}^{-1}$ materials was significantly taller than that of $20 \mathrm{t} \mathrm{ha}^{-1}$, $5 \mathrm{t} \mathrm{ha}^{-1}$ and control plots but was not significantly different from the plant mulched with $10 \mathrm{t} \mathrm{ha}^{-1}$ $(23.9 \mathrm{~cm})$.

At 4 WAT, plant height of tomato was significantly $(\mathrm{P} \leq 0.05)$ influenced by mulching rate. The plants mulched with $15 \mathrm{t} \mathrm{ha}^{-1}$ $(39.9 \mathrm{~cm})$ was significantly taller than other mulching rates while the least mean value $(30.5 \mathrm{~cm})$ was obtained from the control plot which was not significantly different from the plants mulched with $5 \mathrm{t} \mathrm{ha}^{-1}(31.3 \mathrm{~cm})$.

The plant heights of tomato was significantly $(\mathrm{P} \leq 0.05)$ increased by mulching rate at 6 WAT. The highest mean value $(39.9 \mathrm{~cm})$ was obtained from the plants mulched with $15 \mathrm{t}$ ha ${ }^{1}$ which was not significantly different from the plants mulched with $20 \mathrm{t} \mathrm{ha}^{-1}(38.5 \mathrm{~cm})$. Also, the plants mulched with $10 \mathrm{t} \mathrm{ha}^{-1}$ $(35.4 \mathrm{~cm})$ and $5 \mathrm{t} \mathrm{ha} \mathrm{h}^{-1}(33.6 \mathrm{~cm})$ was not significantly different from each other while the least mean value $(29.3 \mathrm{~cm})$ was observed from the un-mulched plants. The interaction effects between mulch material and mulching rate at 2, 4 \& 6 WAT were not significant $(\mathrm{P} \geq 0.05)$.

\section{Number of flowers per plant}

Table 2: Effect of mulch material and mulching rate on number of flowers of tomato plants in 2014 cropping season.

\begin{tabular}{|c|c|c|c|c|c|c|}
\hline \multicolumn{7}{|c|}{ Number of Flowers } \\
\hline \multicolumn{7}{|c|}{ Mulching Rate (t ha- ${ }^{-1}$ ) } \\
\hline Mulch Material & $\mathbf{0}$ & $\mathbf{5}$ & $\mathbf{1 0}$ & $\mathbf{1 5}$ & $\mathbf{2 0}$ & $\begin{array}{c}\text { MM } \\
\text { Mean }\end{array}$ \\
\hline RH & 15.6 & 18.4 & 21.3 & 28.6 & 24.6 & 21.7 \\
\hline GS & 14.2 & 15.7 & 17.2 & 25.1 & 22.4 & 18.9 \\
\hline DG & 14.3 & 16.6 & 19.7 & 22.5 & 26.1 & 19.8 \\
\hline MR Mean & 14.7 & 16.9 & 19.4 & 25.4 & 24.4 & \\
\hline LSD (0.05) MM & $\mathrm{ns}$ & & & & & \\
\hline MR & 4.47 & & & & & \\
\hline MM x MR & $\mathrm{ns}$ & & & & & \\
\hline
\end{tabular}

RH: Rice Husk; GS: Groundnut Shell; DG: Dry Guinea Grass; MM: Mulch Material; MR: Mulching Rate; WAT: Weeks After Transplanting; NS: Not Significant; (P $\leq 0.05)$; LSD: Least Significant Difference

The mean number of flowers of tomato is presented in (Table 2). The number of flowers increased as the mulching rate increased and declined thereafter. The mulch material had no significant $(\mathrm{P} \geq 0.05)$ influence on the number of flowers of tomato plants. The plants mulched with $15 \mathrm{t} \mathrm{ha}^{-1}(24.5)$ and $20 \mathrm{t}$ $\mathrm{ha}^{-1}$ (24.4) significantly had similar number of flowers which were significantly different from the plants mulched with $10 \mathrm{t}$ $\mathrm{ha}^{-1}$ (19.4) and $5 \mathrm{t} \mathrm{ha}^{-1}$ (16.9). The plants mulched with $10 \mathrm{t} \mathrm{ha} \mathrm{h}^{-1}$ was significantly higher than the plots left un-mulched (control) but significantly had similar number of flowers with the plants mulched with $5 \mathrm{t} \mathrm{ha}^{-1}$, respectively. The interactive effects of mulch material and mulching rate was not significantly $(\mathrm{P} \geq 0.05)$ influenced.

\section{Number of fruits per plant}

Table 3: Effect of mulch material and mulching rate on number of fruits per plant of tomato plants in 2014 cropping season.

\begin{tabular}{|c|c|c|c|c|c|c|}
\hline \multicolumn{7}{|c|}{ Number of fruits } \\
\hline Mulching rate (t ha- ${ }^{-1}$ ) \\
\hline RH & 13.1 & 14.5 & 15.1 & 20.7 & 18.8 & 16.4 \\
\hline GS & 12.6 & 14.3 & 15.1 & 23.7 & 19.8 & 17.1 \\
\hline DG & 10.9 & 13.2 & 13.6 & 19.3 & 17.8 & 15 \\
\hline MR Mean & 12.2 & 14 & 14.6 & 21.2 & 18.8 & \\
\hline LSD (0.05) MM & ns & & & & & \\
\hline MR & 3.54 & & & & & \\
\hline MM x MR & ns & & & & & \\
\hline
\end{tabular}

RH: Rice Husk; GS: Groundnut Shell; DG: Dry Guinea Grass; MM Mulch Material; MR: Mulching Rate; WAT: Weeks After Transplanting; NS: Not Significant; (P $\leq 0.05)$; LSD: Least Significant Difference

The mean number of tomato fruits is presented in (Table 3 ). The number of fruits increased as the mulching rate increased and declined thereafter. The mulch material had no significant $(P \geq 0.05)$ effect on the number of tomato fruit. The mulching rate significantly $(\mathrm{P} \leq 0.05)$ affected the number of fruits. The plants mulched with $15 \mathrm{t} \mathrm{ha}^{-1}$ (21.2) significantly gave higher number of fruits than the control plot (12.2), $5 \mathrm{t} \mathrm{ha}^{-1}$ (14.0), and 10t ha-1 (14.6) but was not significantly different from that of $20 \mathrm{t} \mathrm{ha}^{-1}$ (18.8). The interaction effects of mulch material and mulching rate was not significantly $(\mathrm{P} \geq 0.05)$ influenced.

\section{Total fruit yield (t/ha)}

The total fruit yield of tomato increased as the mulching rate increased and declined thereafter as shown in (Table 4). The total fruit yield of the tomato was no significantly $(\mathrm{P} \geq 0.05)$ increased by mulch material treatments. The total fruit yield of tomato was significantly $(\mathrm{P} \leq 0.05)$ influenced by mulching rate. The plant mulched with $15 \mathrm{t} \mathrm{ha}^{-1}\left(23.30 \mathrm{t} \mathrm{ha}^{-1}\right)$ was significantly higher than other values of mulching rates. Mulching rate of $20 \mathrm{t}$ ha $^{-1}\left(17.57 \mathrm{t} \mathrm{ha}^{-1}\right)$ was significantly higher than the plants mulched with $10 \mathrm{t} \mathrm{ha}^{-1}$ (11.90t ha-1), $5 \mathrm{t} \mathrm{ha}^{-1}\left(10.80 \mathrm{t} \mathrm{ha}^{-1}\right)$ and the least was 
obtained from un-mulched plot (8.13t ha-1 $)$. But there was no significant difference between the values of these treatments. The interactive effect of mulch material and mulching rate was not significant $(\mathrm{P} \geq 0.05)$.

Table 4: Effect of mulch material and mulching rate on total fruit yield of tomato plants in 2014 cropping season.

\begin{tabular}{|c|c|c|c|c|c|c|}
\hline \multicolumn{7}{|c|}{ Total Fruit Yield $\left(\mathbf{t}\right.$ ha$\left.^{-1}\right)$} \\
\hline Mulching Rate $\left(\mathbf{t ~ h a}^{-\mathbf{1}}\right)$ \\
\hline Mulch Material & $\mathbf{0}$ & $\mathbf{5}$ & $\mathbf{1 0}$ & $\mathbf{1 5}$ & $\mathbf{2 0}$ & MM Mean \\
\hline RH & 7.8 & 13.7 & 13.4 & 28.8 & 19.3 & 16.6 \\
\hline GS & 9.3 & 9.2 & 13.4 & 23.2 & 18.6 & 14.7 \\
\hline DG & 7.3 & 9.5 & 8.9 & 17.8 & 14.8 & 11.66 \\
\hline MR Mean & 8.13 & 10.8 & 11.9 & 23.3 & 17.6 & \\
\hline LSD (0.05) MM & ns & & & & & \\
\hline MR & 5.18 & & & & & \\
\hline MM x MR & ns & & & & & \\
\hline
\end{tabular}

\section{Soil temperature at 2 WAT}

Table 5: Effect of mulch material and mulching rate on soil temperature at 2 WAT of tomato plants in 2014 cropping season.

\begin{tabular}{|c|c|c|c|c|c|c|c|}
\hline \multicolumn{7}{|c|}{ Moil Temperature $\left({ }^{\mathbf{0}} \mathbf{C}\right)$} \\
\hline Mulch Material & $\mathbf{0}$ & $\mathbf{5}$ & $\mathbf{1 0}$ & $\mathbf{1 5}$ & $\mathbf{2 0}$ & MM Mean \\
\hline \multicolumn{7}{|c|}{ 2WAT 8am } \\
\hline RH & 29.6 & 29.5 & 29.6 & 28 & 28.2 & 29 \\
\hline GS & 30.3 & 29.8 & 28.5 & 27.8 & 28.3 & 28.9 \\
\hline DG & 30 & 30 & 28.8 & 26.8 & 26.3 & 28.4 \\
\hline MR Mean & 30 & 29.8 & 29 & 27.5 & 27.6 & \\
\hline LSD (0.05) MM & ns & & & & & \\
\hline MR & 0.69 & & & & & \\
\hline MM x MR & ns & & & & & \\
\hline \multicolumn{7}{|c|}{$4.00 p m$} & \\
\hline RH & 32.2 & 31.8 & 31 & 30.8 & 31 & 31.4 \\
\hline GS & 32.3 & 31.6 & 32 & 30.4 & 30.5 & 31.3 \\
\hline DG & 33.4 & 32 & 31 & 29.5 & 29.5 & 31.1 \\
\hline MR Mean & 32.6 & 31.8 & 31 & 30.2 & 30.3 & \\
\hline LSD (0.05) MM & ns & & & & & \\
\hline MR & 0.7 & & & & & \\
\hline MM x MR & ns & & & & & \\
\hline
\end{tabular}

RH: Rice Husk; GS: Groundnut Shell; DG: Dry Guinea Grass; MM: Mulch Material; MR: Mulching Rate; WAT: Weeks After Transplanting; NS: Significant; (P $\leq 0.05)$; LSD: Least Significant Difference

The mean soil temperature is presented in (Table 5). The soil temperature decreased as the mulching rate increased irrespective of the mulch material applied. Mulch material had no significant $(\mathrm{P} \geq 0.05)$ effect on soil temperature in the morning and afternoon at 2 WAT.

The soil temperature was significantly $(\mathrm{P} \leq 0.05)$ influenced by mulching rate in the morning. The un-mulched plots (control) recorded the highest soil temperature of $30.0{ }^{\circ} \mathrm{C}$ which was significantly higher than the mean values $\left(29.8{ }^{\circ} \mathrm{C}\right.$, $29.0{ }^{\circ} \mathrm{C}$ ) obtained at $5 \mathrm{t} \mathrm{ha} \mathrm{a}^{-1}$ and $10 \mathrm{tha}^{-1}$ while the least mean value $\left(27.5^{\circ} \mathrm{C}\right)$ was obtained from the plants mulched with $15 \mathrm{t}$ ha $^{-1}$ which was not significantly different from that of $20 \mathrm{t} \mathrm{ha}^{-1}$ $\left(27.6{ }^{0} \mathrm{C}\right)$. The same trend was observed in the afternoon soil temperature. Tomato grown in un-mulched plots significantly gave the highest mean value $\left(32.6{ }^{\circ} \mathrm{C}\right)$ which was significantly higher than the plants mulched with $5 \mathrm{t} \mathrm{ha}^{-1}\left(31.8^{\circ} \mathrm{C}\right)$ and $10 \mathrm{t} \mathrm{ha}^{-1}$ $\left(31.2{ }^{\circ} \mathrm{C}\right)$ and the least mean value $\left(30.2{ }^{\circ} \mathrm{C}\right)$ was obtained with $15 \mathrm{t} \mathrm{ha}^{-1}$. The interaction of mulch material and mulching rate did not significantly $(\mathrm{P} \geq 0.05)$ influence morning and afternoon soil temperatures.

\section{Soil temperature at 4 WAT}

Table 6: Effect of mulch material and mulching rate on soil temperature at 4 WAT of tomato plants in 2014 cropping season.

\begin{tabular}{|c|c|c|c|c|c|c|}
\hline \multicolumn{7}{|c|}{ Soil Temperature $\left({ }^{\circ} \mathrm{C}\right)$} \\
\hline \multicolumn{7}{|c|}{ Mulching Rate (t ha-1) } \\
\hline $\begin{array}{c}\text { Mulch Ma- } \\
\text { terial }\end{array}$ & $\mathbf{0}$ & 5 & 10 & 15 & 20 & MM Mean \\
\hline \multicolumn{7}{|c|}{ 4WAT 8am } \\
\hline RH & 30 & 29 & 29.2 & 28 & 28 & 28.8 \\
\hline GS & 30 & 29.4 & 29.3 & 28 & 26.3 & 28.6 \\
\hline DG & 30.2 & 29.8 & 28.2 & 27.5 & 26.5 & 28.4 \\
\hline MR Mean & 30.1 & 29.4 & 28.9 & 27.8 & 27.6 & \\
\hline $\begin{array}{l}\text { LSD (0.05) } \\
\text { MM }\end{array}$ & ns & & & & & \\
\hline MR & 0.91 & & & & & \\
\hline $\mathrm{MM} \times \mathrm{MR}$ & ns & & & & & \\
\hline \multicolumn{7}{|c|}{$4.00 \mathrm{pm}$} \\
\hline RH & 32.2 & 31 & 30.6 & 29.5 & 29 & 30.5 \\
\hline GS & 32.5 & 30.8 & 30.3 & 29.4 & 28.3 & 30.3 \\
\hline DG & 32.2 & 30.8 & 30.6 & 30 & 28.3 & 30.4 \\
\hline MR Mean & 32.3 & 30.9 & 30.5 & 29.6 & 28.5 & \\
\hline $\begin{array}{l}\text { LSD (0.05) } \\
\text { MM }\end{array}$ & ns & & & & & \\
\hline MR & 1.21 & & & & & \\
\hline $\mathrm{MM} \times \mathrm{MR}$ & ns & & & & & \\
\hline
\end{tabular}

RH: Rice Husk; GS: Groundnut Shell; DG: Dry Guinea Grass; MM: Mulch Material; MR: Mulching Rate; WAT: Weeks After Transplanting; NS: Significant; (P $\leq 0.05)$; LSD: Least Significant Difference

There was no significant $(\mathrm{P} \geq 0.05)$ effect of mulch material in morning and afternoon soil temperatures at 4 WAT (Table 6). Mulching rate had significant $(P \leq 0.05)$ influence on soil temperature. In the morning, un-mulched plots recorded the highest mean value $\left(30.1{ }^{\circ} \mathrm{C}\right)$ which was significantly higher than the plants mulched with $10 \mathrm{t} \mathrm{ha} \mathrm{H}^{-1}\left(28.9{ }^{\circ} \mathrm{C}\right)$ but was not significantly different from the plants mulched with $5 \mathrm{t} \mathrm{ha}^{-1}(29.4$ ${ }^{0} \mathrm{C}$ ) while the least mean value $\left(27.8{ }^{\circ} \mathrm{C}, 27.6{ }^{\circ} \mathrm{C}\right)$ were received from 15 and $20 \mathrm{tha}^{-1}$. In the afternoon, the tomato plants left un-mulched recorded the highest mean value $\left(32.3^{\circ} \mathrm{C}\right)$ which 
was significantly higher than the plants mulched with $5 t$ ha $^{-1}$, $10 \mathrm{t} \mathrm{ha} \mathrm{a}^{-1}$ and $15 \mathrm{t} \mathrm{ha}^{-1}$ while the least mean value $\left(28.5^{\circ} \mathrm{C}\right)$ was obtained from the plants mulched with $20 \mathrm{t} \mathrm{ha}^{-1}$. The interaction effects of mulch material and mulching rate on morning and afternoon soil temperatures were not significant $(\mathrm{P} \leq 0.05)$.

\section{Soil temperature at 6 WAT}

Table 7: Effect of mulch material and mulching rate on soil temperature at 6 WAT of tomato plants in 2014 cropping season.

\begin{tabular}{|c|c|c|c|c|c|c|}
\hline \multicolumn{7}{|c|}{ Soil Temperature $\left({ }^{\circ} \mathrm{C}\right)$} \\
\hline \multicolumn{7}{|c|}{ Mulching Rate ( $\mathrm{t} \mathrm{ha}^{-1}$ ) } \\
\hline $\begin{array}{c}\text { Mulch } \\
\text { Material }\end{array}$ & $\mathbf{0}$ & 5 & 10 & 15 & 20 & $\begin{array}{c}\text { MM } \\
\text { Mean }\end{array}$ \\
\hline \multicolumn{7}{|l|}{ 6WAT 8am } \\
\hline RH & 31.4 & 29.8 & 29 & 28.5 & 28.4 & 29.4 \\
\hline GS & 31.3 & 29.8 & 29.8 & 28.2 & 28.5 & 29.5 \\
\hline DG & 31 & 29.5 & 29.2 & 28.5 & 28 & 29.2 \\
\hline MR Mean & 31.2 & 29.7 & 29.3 & 28.4 & 28.4 & \\
\hline $\begin{array}{l}\text { LSD (0.05) } \\
\text { MM }\end{array}$ & ns & & & & & \\
\hline MR & 0.56 & & & & & \\
\hline MM x MR & ns & & & & & \\
\hline \multicolumn{7}{|l|}{$4.00 \mathrm{pm}$} \\
\hline RH & 31.3 & 29.7 & 29 & 29 & 28.7 & 29.5 \\
\hline GS & 31.7 & 29.7 & 29.7 & 28.7 & 28 & 29.6 \\
\hline DG & 32.3 & 29.7 & 29.3 & 28.7 & 28.7 & 29.7 \\
\hline MR Mean & 31.8 & 29.7 & 29.3 & 28.8 & 28.5 & \\
\hline $\begin{array}{c}\text { LSD (0.05) } \\
\text { MM }\end{array}$ & ns & & & & & \\
\hline MR & 0.71 & & & & & \\
\hline MM x MR & ns & & & & & \\
\hline
\end{tabular}

RH: Rice Husk; GS: Groundnut Shell; DG: Dry Guinea Grass; MM: Mulch Material; MR: Mulching Rate; WAT: Weeks After Transplanting; NS: Significant; (P $\leq 0.05)$; LSD: Least Significant Difference

The mean soil temperature is presented in (Table 7). The mulch material had no significant $(\mathrm{P} \geq 0.05)$ effect on morning and afternoon soil temperatures at 6 WAT. The soil temperature was significantly $(\mathrm{P} \leq 0.05)$ influenced by mulching rate in the morning and afternoon soil temperatures. In the morning, unmulched plots significantly gave the highest soil temperature $\left(31.8^{\circ} \mathrm{C}\right)$ which was significantly higher than the values of other mulching rates. The plants mulched with $5 \mathrm{t} \mathrm{ha}^{-1}\left(29.7^{\circ} \mathrm{C}\right)$ and 10 t ha $^{-1}\left(29.3^{\circ} \mathrm{C}\right)$ was not significantly different from each other. The plants mulched with $20 \mathrm{t} \mathrm{ha}^{-1}$ had the least decreased mean value $\left(28.5^{\circ} \mathrm{C}\right)$ which was not significantly different from that of $15 \mathrm{tha}^{-1}\left(28.8^{\circ} \mathrm{C}\right)$. The interactive effects of mulch material and mulching rate was not significantly $(\mathrm{P} \geq 0.05)$ influenced.

\section{Soil moisture content at 2,4 and 6 WAT}

The mean soil moisture content is presented in (Table 8). Mulch materials had no significant $(P \geq 0.05)$ effect on soil moisture content at 4 and 6 WAT. Mulch material had significant $(\mathrm{P} \leq 0.05)$ influence on soil moisture content at 2 WAT. Mulch materials of groundnut shell $(3.3 \%)$ and dry guinea grass (3.1\%) were not significantly different from each other but were significantly higher than the rice husk mulch $(2.9 \%)$. The soil moisture content increased as the mulching rate increases from $0 \mathrm{t} \mathrm{ha} \mathrm{a}^{-1}$ to $20 \mathrm{t} \mathrm{ha}^{-1}$. Tomato plants mulched with $20 \mathrm{t} \mathrm{ha}^{-1}(4.3 \%)$ was significantly higher than that of $15 \mathrm{tha}^{-1}(3.7 \%)$ which was significantly higher than $10 \mathrm{t} \mathrm{ha}^{-1}(3.1 \%)$ and $5 \mathrm{t} \mathrm{ha}^{-1}(2.6 \%)$ while the least mean value $(1.7 \%)$ was obtained from un-mulched plot.

The soil moisture content was significantly $(\mathrm{P} \leq 0.05)$ influenced by mulching rate at 4 WAT. Tomato plants mulched with $20 \mathrm{t} \mathrm{ha}^{-1}(7.1 \%)$ was significantly higher than that of $10 \mathrm{t}$ $\mathrm{ha}^{-1}(4.8 \%)$ and $5 \mathrm{t} \mathrm{ha}^{-1}(3.7 \%)$. But was not significantly different from $15 \mathrm{t} \mathrm{ha}^{-1}(6.6 \%)$ while the least mean value $(2.6 \%)$ was obtained from the control plot. Similarly, the same trend was observed at 6 WAT. The plant mulched with $20 \mathrm{t} \mathrm{ha}^{-1}(6.6 \%)$ was significantly higher than the plants mulched with $10 \mathrm{t} \mathrm{ha}^{-1}$ $(5.2 \%)$ and $5 t^{-1} \mathrm{a}^{-1}(4.4 \%)$, respectively. But was not significantly different from that of $15 \mathrm{t} \mathrm{ha}^{-1}(5.9 \%)$ and the least mean value $(3.0 \%)$ was received from the un-mulched plot. The interaction effects of mulch material and mulching rate was not significantly $(\mathrm{P} \geq 0.05)$ influenced at 2,4 and 6 WAT.

Table 8: Effect of mulch material and mulching rate on soil moisture content of tomato plants in 2014 cropping season.

\begin{tabular}{|c|c|c|c|c|c|c|}
\hline \multicolumn{7}{|c|}{ Soil Moisture Content (\%) } \\
\hline \multicolumn{7}{|c|}{ Mulching Rate (t ha-1) } \\
\hline Mulch Material & $\mathbf{0}$ & 5 & 10 & 15 & 20 & MM Mean \\
\hline & & & 2WAT & & & \\
\hline $\mathrm{RH}$ & 1.8 & 2.5 & 2.4 & 3.8 & 4.1 & 2.9 \\
\hline GS & 2 & 2.6 & 3.4 & 3.7 & 4.6 & 3.3 \\
\hline DG & 1.4 & 2.7 & 3.6 & 3.7 & 4.3 & 3.1 \\
\hline MR Mean & 1.7 & 2.6 & 3.1 & 3.7 & 4.3 & \\
\hline LSD (0.05) MM & 0.32 & & & & & \\
\hline MR & 0.34 & & & & & \\
\hline
\end{tabular}


Current Trends in Biomedical Engineering \& Biosciences

\begin{tabular}{|c|c|c|c|c|c|c|}
\hline MM x MR & ns & & & & & \\
\hline \multicolumn{7}{|c|}{4 WAT } \\
\hline $\mathrm{RH}$ & 2.7 & 3.4 & 4.5 & 6.4 & 6.7 & 4.7 \\
\hline GS & 2.3 & 3.9 & 4.4 & 7 & 7.6 & 5 \\
\hline DG & 2.9 & 3.9 & 5.4 & 6.3 & 7 & 5.1 \\
\hline MR Mean & 2.6 & 3.7 & 4.8 & 6.6 & 7.1 & \\
\hline LSD (0.05) MM & ns & & & & & \\
\hline MR & 0.58 & & & & & \\
\hline MM x MR & ns & & & & & \\
\hline \multicolumn{7}{|c|}{6 WAT } \\
\hline RH & 3.3 & 4.3 & 5.2 & 5.7 & 6.4 & 5 \\
\hline GS & 3 & 4.8 & 5.1 & 6 & 6.8 & 5.1 \\
\hline DG & 2.8 & 4.1 & 5.3 & 5.9 & 6.6 & 4.9 \\
\hline MR Mean & 3 & 4.4 & 5.2 & 5.9 & 6.6 & \\
\hline LSD (0.05) MM & ns & & & & & \\
\hline MR & 0.83 & & & & & \\
\hline MM x MR & ns & & & & & \\
\hline
\end{tabular}

RH: Rice Husk; GS: Groundnut Shell; DG: Dry Guinea Grass; MM: Mulch Material; MR: Mulching Rate; WAT: Weeks After Transplanting; NS: Significant; (P $\leq 0.05)$; LSD: Least Significant Difference

\section{Discussion}

Reports by Liasu \& Abdul Kabir [8] stated that mulching is a layer of material on the surface of the soil used to keep soil moist or to serve a wide variety of purposes. Organic mulches are those derived from the dead plant and animal tissues, which apart from soil protection also serve as nutrient sources when they decay. Findings from Kayum et al. [9] revealed that mulching tomato plants with the use of water hyacinth, straw, am-ada leaf and banana leaf showed significant effect on growth and yield components and thus increase the yield. The significant plant height of $39.9 \mathrm{~cm}$ obtained with the mulching rate of $15 \mathrm{t} \mathrm{ha}^{-1}$ from the present study agrees with the report of Liasu \& Abdul Kabir [8] who stated that tomato plants subjected to mulching exhibited the highest plant height when compared with control. The above authors in their findings also stated that the tomato plants subjected to mulching exhibited the highest number of leaves per plant than the control plot.

In the current study, mulching rate of $15 \mathrm{t}$ ha- 1 and $20 \mathrm{t}$ ha-1 produced number of flowers of 25.4 and 24.4 that were significantly higher than the values of other mulching rates. This may be attributed to the fact that the mulching application rate was higher thereby retaining moisture in the soil which promoted flower formation. This is in agreement with Anon [5] who reported that the thicker the mulch material the more water is retained in the soil to serve as a good medium for plant growth, development and efficient crop production. The results obtained from this study revealed that rice husk mulch gave higher number of fruits than other mulch materials. This agrees with the report of Akhtar et al. [6] who reported that natural mulches such as leaf, rice straw, dead leaves and compost have been used for centuries to increase fruit per plant, fruit length, fruit size, average fruit weight and yield. Findings in this study also agrees with those of Kayum et al. [9] who stated that mulching showed significant effect on growth, yield components and thus on the yield of tomato.

The significant highest total fruit yield of $23.30 \mathrm{t} \mathrm{ha}^{-1}$ produced from the plants mulched with $15 \mathrm{t} \mathrm{ha}^{-1}$ in this study was at the upper value of $14.00 \mathrm{t} \mathrm{ha}^{-1}$ reported by Gudugi et al. [14] and 21.47 $\mathrm{ha}^{-1}$ reported by Elkner et al. [16]. The results of the current study is in conformity with Ertek et al. [23] who revealed that mulching tomato plants at the rate of 10 to $20 \mathrm{t}$ ha-1 will give better yield using mulch materials such as green leaves, dried leaves and coconut fronds.

Findings from the current study indicated that rice husk mulch and mulching rate of $15 \mathrm{t} \mathrm{ha}^{-1}$ significantly gave the decreased soil temperature of $27.5{ }^{0} \mathrm{C}$ at 2 WAT which is in agreement with the findings of Anyanwu et al. [24] who reported that tomato is a warm season crop and it grows best at a temperature of $24{ }^{\circ} \mathrm{C}-29{ }^{\circ} \mathrm{C}$ under organic waste. This is also in line with Ajay \& Shashi [20] who stated that soil temperature and yield of tomato was significantly improved with mulching over control.

The results obtained from the current study proved that groundnut shell and dry guinea grass mulches significantly 
increased the soil moisture content. This agrees with Brault et al. [21] who stated that traditionally, organic mulches such as dry grass and plant residue mulches are often used to warm soil early in the season. Soil mulching not only reduces the soil evaporation and weed growth but also improves the aerial environment around the plants which facilitate plant growth and yield. The result from the present study showed that the plants mulched with $20 \mathrm{t} \mathrm{ha}^{-1}$ significantly gave better soil moisture content of $7.1 \%$ at 4 WAT. This reconfirmed Agbo [15] who stated that generally, the higher the amount of mulch applied, the better the water retention, growth and yield of okra. Similarly, Agele et al. [22] reported that mulching of sunflower plants with the organic mulch materials improved soil moisture status. They however, stated that dry grass and teak leaf increased soil moisture contents significantly over those obtained under polythene sheet mulch and control. They further revealed that soil moisture content improved considerably following decreased in soil temperature in plots mulched with dry grass and teak leaves.

\section{Conclusion}

Based on the research findings, it can be concluded that rice husk mulch gave better fruit yield and most reduced soil temperature while groundnut shell and dry guinea grass mulches recorded better soil moisture content. More so, the plants mulched with $15 \mathrm{t} \mathrm{ha}^{-1}$ gave the highest fruit yield and the lowest soil temperature and the plants mulched with $20 \mathrm{t}$ ha- 1 gave the highest soil moisture content. These therefore could be recommended for the tomato farmers within the study areas.

\section{References}

1. Zeidan $O$ (2005) Tomato production under protected condition. Ministry of Agriculture and Rural Development. The centre for International Agriculture Development Cooperation, pp. 43-44.

2. Villareal RL (1980) Tomato in the tropics. West view Press Boulder, Colorado, p. 174.

3. Omar Z (2005) Tomato production under protected conditions. Published by Mashav, Cinad co and the peres centre for peace project coordinator, pp. 71-112.

4. Balarabe S (2012) Tomato production in Nigeria: issues and prospects. Ministry of Agriculture and Rural Development Kano, Kano State, Nigeria.

5. Anon (2009) National Horticultural Research Institute. Annual Report for vegetable production.

6. Akhtar S, Wahid A, Akram M, Rausl E (2001) Some growth, photosynthetic and anatomical attributes of sugarcane genotypes under $\mathrm{NaCl}$ salinity. International Journal of Agriculture and Biology 3(4): 439-443.

7. Enan SA (2004) Effect of transplanting and soil application of boron and zinc on yield and quality of sugar beet. Ph.D. Thesis Al-Azhar University of Egypt, pp. 150-152.
8. Liasu MO, Abdul kabir KA (2007) Influence of tithonia diversifolia leaf mulch and fertilizer application on the growth and yield of potted tomato plants. American-Eurasian Journal of Agriculture and Environmental Science 2(4): 335-340.

9. Kayum MA, Asaduzzaman M, Haque MZ (2008) Effect of indigenous mulches on growth and yield of tomato. Journal of Agriculture and Rural Development 6(1\& 2): 1-6.

10. Hooda RS, Singh J, Malik YS, Batra VK (1999) Influence of direct seedling, transplanting time and mulching on tomato yield. Vegetable Science 26(2): 140 -142.

11. Bhagat RM, Acharya CL (1988) Soil water dynamics during wheat growth under different management practices. Journal of Indian Society. Soil Science 36: 389-396.

12. Walter B (1988) Influence of bark mulch on water balance, soil water quality, mineralization and nitrification in skeletal Devonian viney and soils. Horticulture 59(9): 835

13. George A (2004) Horticuture principles and practices, pp. 709-710.

14. Gudugi IAS, Odofin AJ, Adeboye MKA, Oladiran JA (2012) Agronomic characteristics of tomato as influenced by irrigation and mulching. Advances in Applied Science Research 3(5): 2539-2543.

15. Agbo, Reginald Sitsofe Kwaku (2000) The effects of L. Leucocephala and G. Sepium mulches and their mixtures on the growth and yield of okra. Master of Science Degree Thesis, Kwame Nkrumah University of Science and Technology, Kumasi. pp. 44-45.

16. Elkner K, Kaniszewski S, Gerasopoulos D, Passam H (1991) Effect of drip irrigation and mulching on quality of tomato fruits. Acta Horticulturae 379: 175-180.

17. Norman QA, Clive AE (2005) Effects of vermicompost on plant growth. Paper presented during the International Symposium workshop on vermi Technologies for Developing Countries, Los Banos, Philippines, pp. 16-18.

18. FAO (1999) Soil fertility initiation for Sub-Saharan Africa. World Soil Resource Reports 85: 82.

19. Wood AW (1991) Management of crop residues following green harvesting of sugarcane in north Queensland. Soil and Tillage Research 20(1): 69-85.

20. Ajay KS, Shashi K (2012) Effect of black plastic mulch on soil temperature and tomato yield in mid hills of Garhwal Himalayas. Journal of Horticulture and Forestry 4(4): 78-80.

21. Brault D, Stewart KA, Jenni S (2002) Growth, development and yield of head lettuce cultivated on paper and polyethylene mulch. Horticultural Science 37(1): 92-94.

22. Agele SO, Olaore JB, Akinbode FA (2010) Effect of some mulch materials on soil physical properties, growth and yield of sunflower (Helianthus annuus, L). Advances in Environmental Biology 4(3): 368-375.

23. Ertek A, Sensoy S, Kuecuekyumuk C, Gedik I (2004) Agricultural water management 67: 63-76.

24. Anyanwu AC, Anyanwu BO, Anyanwu VA (2001) A Textbook of Agricultural Science for Schools and Colleges Published by AfricanaFeb Publishers Limited, pp. 71-75. 
This work is licensed under Creative Commons Attribution 4.0 License

DOI: 10.19080/CTBEB.2017.10.555783
Your next submission with Juniper Publishers will reach you the below assets

- Quality Editorial service

- Swift Peer Review

- Reprints availability

- E-prints Service

- Manuscript Podcast for convenient understanding

- Global attainment for your research

- Manuscript accessibility in different formats

( Pdf, E-pub, Full Text, Audio)

- Unceasing customer service

Track the below URL for one-step submission https://juniperpublishers.com/online-submission.php 